\title{
Os benefícios da atividade rítmica no cotidiano escolar
}

\section{Los beneficios de la actividad rítmica en la vida escolar cotidiana}

DOI: $10.46814 / \operatorname{lajdv} 4$ n1-021

Recebimento dos originais: 03/01/2022

Aceitação para publicação: 28/02/2022

\author{
Gleison Rodrigues Ribeiro \\ Institución: Curso de - UNIESP \\ Dirección: Osvaldo Cruz, 341. Presidente Venceslau - SP \\ Correo electrónico: tiogleison@hotmail.com
}

\begin{abstract}
RESUMO
A atividade rítmica se constitui numa forma de expressão corporal e tais atividades podem ser definidas por comunicação e expressão através de meio de sons e gestos, tratando-se especificamente das danças, músicas e brincadeiras cantadas. Nessas atividades rítmicas encontram-se subsídios para desenvolver o processo de informação e formação dos códigos corporais. Nota-se que à maioria dos professores que atuam nas escolas tem dificuldades de desenvolver a dança e as atividades rítmicas. O objetivo será o de valorizar a realização das atividades rítmicas por meio das aulas de Educação Física como um dos elementos na construção da alfabetização do aluno na fase pré-escolar. A dança se apresenta enquanto forma de comunicação, considerada a mais antiga, desde os tempos primitivos, os homens já utilizavam para expressar seus sentimentos e desejos, "a dança é um modo de existir", sendo assim a dança pode ser uma experiência da beleza onde os corpos são múltiplos e conscientes da própria mentalidade e sensíveis à expressividade do outro". As atividades rítmicas pertencentes à cultura corporal, podendo ser desenvolvida nas aulas de Educação Física Escolar, de forma coerente e dinâmica, por meio desta área do conhecimento pode ser desenvolvido os aspectos psicomotores e sócio afetivo dos alunos. Está evidente que as atividades rítmicas e a dança são conteúdos, capazes de contemplar diversas finalidades no processo de ensino e aprendizagem dos alunos. Essa prática corporal pode estar na escola de acordo com os pressupostos educacionais e ser adaptada conforme as necessidades e características no contexto escolar. Sendo assim, a Educação Física deve permitir que os alunos participem ativamente das aulas considerando as suas próprias percepções. Metodologia: este trabalho tem fundamento bibliográfico e a pesquisa cunho qualitativo. Conclui-se: ao vivenciar estas práticas corporais, o aluno poderá se desenvolver o esquema corporal, estrutura espacial, orientação temporal junto com os aspectos psicomotor e sócio afetivo, assim os sujeitos poderão ter oportunidades e vivências para se posicionar de forma crítica perante as circunstancias que lhe são apresentadas no seu dia a dia.
\end{abstract}

Palavras-chave: atividade rítmica, escola, educação física.

\section{RESUMEN}

La actividad rítmica es una forma de expresión corporal y dichas actividades pueden definirse como comunicación y expresión a través de sonidos y gestos, concretamente a través de bailes, canciones y juegos cantados. En estas actividades rítmicas hay ayudas para desarrollar el proceso de información y formación de códigos corporales. Se observa que la mayoría de los profesores que trabajan en las escuelas tienen dificultades para desarrollar actividades de danza y ritmo. El objetivo es valorar las actividades rítmicas en las clases de Educación Física como uno de los elementos en la construcción de la alfabetización de los alumnos de preescolar. La danza se presenta como una forma de 
comunicación, considerada la más antigua, desde tiempos primitivos, los hombres ya utilizaban para expresar sus sentimientos y deseos, "la danza es una forma de existir", siendo así la danza puede ser una experiencia de la belleza donde los cuerpos son múltiples y conscientes de su propia mentalidad y sensibles a la expresividad del otro". Las actividades rítmicas pertenecen a la cultura corporal y pueden desarrollarse en las clases de Educación Física Escolar de forma coherente y dinámica; a través de esta área de conocimiento se pueden desarrollar los aspectos psicomotrices y socioafectivos de los alumnos. Es evidente que las actividades rítmicas y la danza son contenidos capaces de contemplar varios propósitos en el proceso de enseñanza y aprendizaje de los alumnos. Esta práctica corporal puede ser en la escuela según los supuestos educativos y adaptarse según las necesidades y características del contexto escolar. Por lo tanto, la Educación Física debe permitir que los alumnos participen activamente en las clases teniendo en cuenta sus propias percepciones. Metodología: Este trabajo se basa en la bibliografía y la investigación es cualitativa. Conclusión: a través de la experimentación de estas prácticas corporales, el alumno podrá desarrollar el esquema corporal, la estructura espacial, la orientación temporal junto con los aspectos psicomotrices y socio-afectivos, por lo que los sujetos tendrán oportunidades y experiencias para posicionarse de forma crítica ante las circunstancias que se presentan en su vida cotidiana.

Palabras clave: actividad rítmica, la escuela, educación física. 